\title{
STREAMFLOW CHANGES IN MESOSCALE LOWLAND CATCHMENT UNDER FUTURE CLIMATE CONDITIONS
}

\author{
URSZULA SOMOROWSKA, IZABELA PIĘTKA \\ Department of Hydrology \\ Faculty of Geography and Regional Studies \\ University of Warsaw \\ e-mail: usomorow@uw.edu.pl
}

\begin{abstract}
The objective of this study was to investigate the performance of streamflow in a lowland mesoscale catchment in Poland under current and future climate conditions. Simulations of hypothetical streamflow in the future climate were facilitated by meteorological data sets from ensemble simulations from all over Europe with the Regional Climate Model CLM. Projections of precipitation and air temperature for the $21^{\text {st }}$ century under the SRES A1B scenario were used as an input to the hydrological model simulating streamflow at the daily time scale. The combination of relatively moderate increase of annual precipitation sum and mean air temperature might cause lower annual discharges. The possible decrease in stream water resources might be a signal of reduced subsurface recharge and land over drying processes.
\end{abstract}

KEY WORDS: streamflow modelling, climate changes, mesoscale catchment, Poland.

\section{INTRODUCTION}

The nowadays observed climate changes associated the global warming have an increasing impact on the environment, including the aquatic environment. This also applies to the natural environment in Poland. The widening of the water deficit in natural circulation is particularly felt in the central lowlands belt, creating the need to 
assess stream water resources. A projection of the climatic water balance for Poland indicates the possibility of increasing the water deficit, especially during the summer (Szwed et al. 2010). The need to protect water resources and the requirement to cope with extreme hydrological events (Projekt... 2008) creates the necessity of detailed studies at different geographical scales (Soczyńska, Gutry-Korycka 2000). In the changing climate, with increasing air temperature and precipitation changes, stream water resources can be significantly transformed. There have been quite a number of studies addressing the problem of hydrological consequences of climate change. A recently reported global-scale analysis confirms the projected changes of seasonal river flow dynamics in basins where winter precipitation is currently dominated by snowfall (Döll, Müller Schmied 2012). In these regions, winter or spring flows are projected to increase, while summer flows are foreseen to presumably decrease. In most regions north of $35^{\circ} \mathrm{N}$, discharge during summer months is projected to decrease. However, the conclusions on how climate change might affect runoff regimes in the future significantly depend on the assumptions concerning the reference period, as well as on projections of different Global Circulation Models, which diverge widely (Sperna Weiland et al. 2012). Going from global scale to mesoscale the question arises to what extend water resources of a lowland catchment could be limited in the future.

The overall aim of this research was to assess stream water resources of the Liwiec river in the context of the changing climate. The target was to predict what could happen with the river regime if the climate pattern continues on its current track, projecting a rise of air temperatures and precipitation. The catchment area is $2471 \mathrm{~km}^{2}$ at the Łochów cross-section (Fig. 1). The catchment has a gently rolling topography with denivelation reaching $140 \mathrm{~m}$. The scheme of the research procedure is presented in Figure 2. In order to assess the hypothetical future changes in the river regime, the rainfall-runoff modeling approach was applied. Continuous discharge simulations were performed using the HBV-light hydrology model (Seibert 1997; Seibert 2005; Seibert, Vis 2012). First, the model was calibrated and validated in the reference period and then the discharge simulations in the projected climate conditions were analysed. The selected meteorological data acquired from the Regional Climate Model CLM (Hollweg et al. 2008) were applied as an input to the calibrated hydrological model. Runs of CLM were forced with the output of the ECHAM5/MPIOM global climate model. These experimental simulations of regional climate were computed by the "Model and Data" group of the Max Planck Institute for Meteorology (MPI-M) in Hamburg. Precipitation and air temperature data were obtained from the CLM simulations of the regional climate in the $20^{\text {th }}$ century $(1961-2000)$ and the $21^{\text {st }}$ century (2021-2060). 


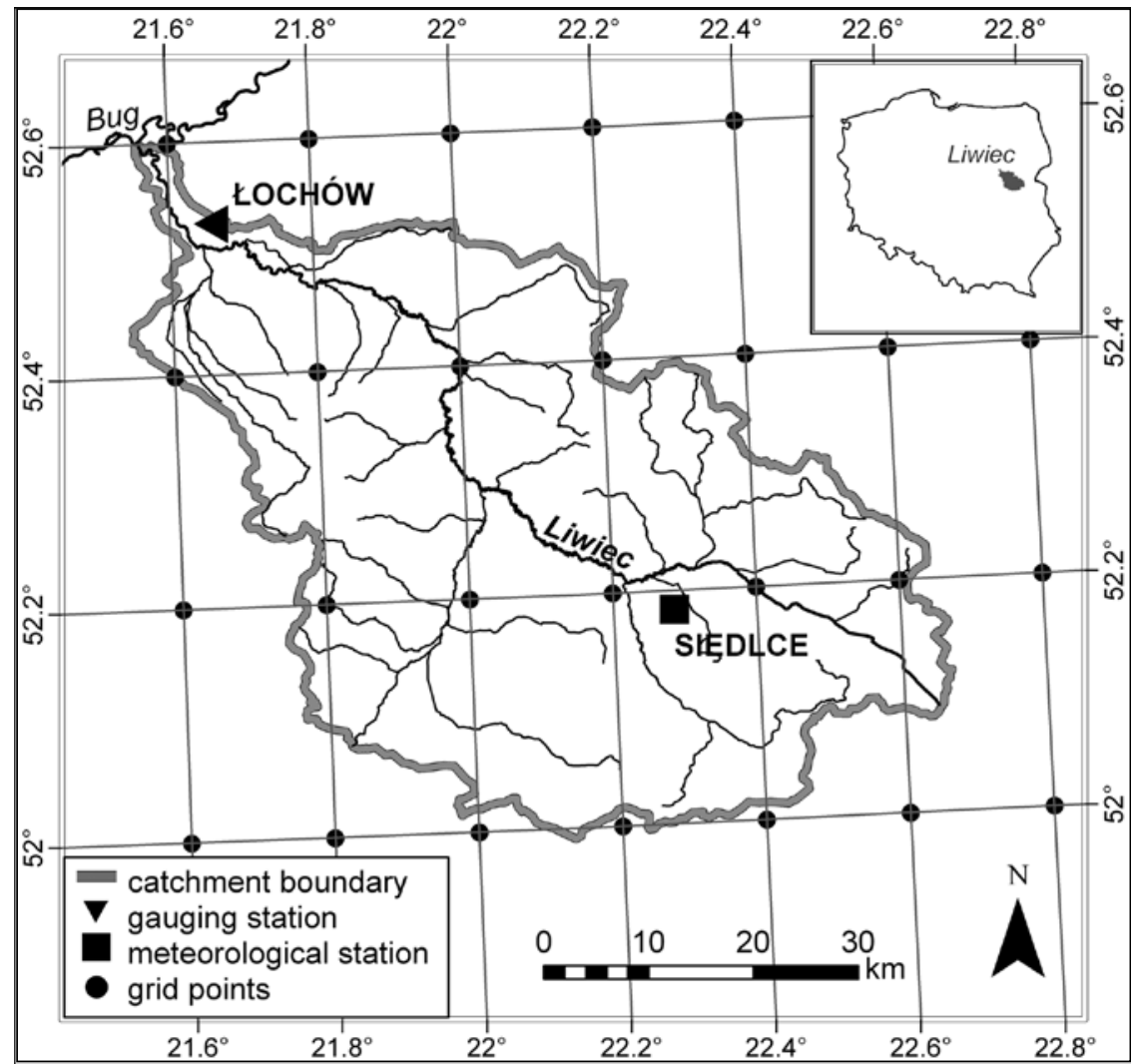

Figure 1. Location of the catchment area

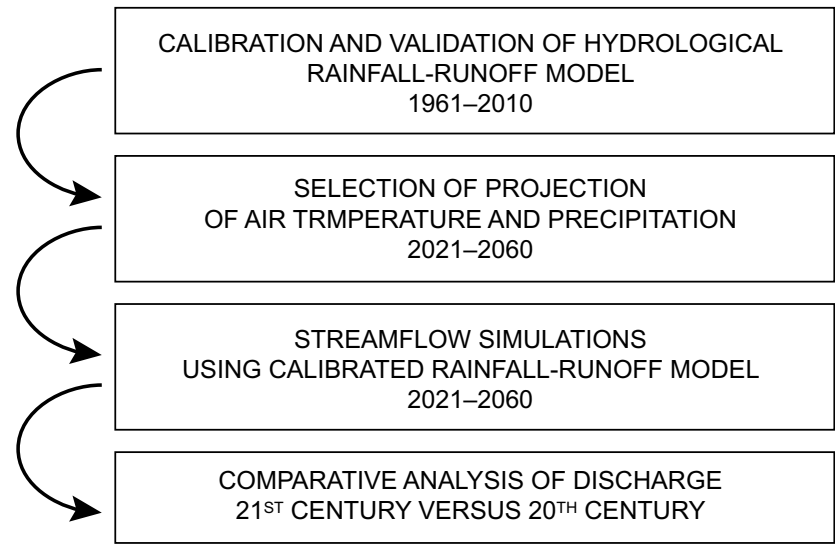

Figure 2. Scheme of the research procedure 


\section{SUPPORTING DATA AND METHODS OF ANALYSIS}

Daily data of streamflow and precipitation were acquired for the reference period of the years 1961-2011. Streamflows concern the Liwiec river at the Lochów crosssection, whereas precipitation and temperature are registered at the Siedlce rain-gauge station. Long-term mean monthly values of potential evapotranspiration were received from the MARS-STAT dataset (MARS 2007). Daily data in the projection period of the years 2021-2060, as well as in the reference period of the years 1961-2000 were extracted from the CLM runs comprising sets of precipitation, air temperature and evapotranspiration acquired in grid cells in the catchment area. They were retrieved in the Net-CDF format and processed to get the spatially averaged mean catchment values of the considered variables. The output variables from the CLM runs for the $21^{\text {st }}$ century concern the SRES A1B Emissions Scenario. The CLM climate simulations show a systematic bias in the precipitation data when compared with the observations in the reference period of the years 1961-2000. A correction method was used to ensure high consistency with the precipitation amount. The rain gauge station data from Siedlce were used to correct the bias. Since the CLM simulated precipitation in the $20^{\text {th }}$ century was distinctly higher than that at the rain gauge station located within the catchment, the bias correction adjusts the precipitation within the catchment in the $21^{\text {st }}$ century to values lower than the projected data. The correction factor to correct evapotranspiration in the $21^{\text {st }}$ century was similarly calculated.

The Swedish HBV model (sw. Hydrologiska Byråns Vattenbalansavdelning model) in the HBV-light version (Seibert 2005; Seibert, Vis 2012) was used to simulate the streamflow hydrograph. It is a conceptual model extensively tested in operational hydrology in many countries. The advantage of using this model is a relatively small number of its parameters, easily available both for the observational period in the $20^{\text {th }}$ century and for the climate projections in the $21^{\text {st }}$ century. The input to the model are precipitation, evapotranspiration and air temperature, which enables the separation of solid and liquid forms of precipitation. The catchment system is symbolized by three sub-systems in the form of a fictional tank of the unsaturated zone, and the upper and the lower reservoirs of groundwater.

The following steps were required to conduct the analysis:

- the calibration and validation of the hydrological model based on data in the reference period covering the years 1961-2000;

- a selection of the climate projection and acquisition of the meteorological variables in the projection period covering the years 2021-2060;

- discharge simulations in the projection period using the calibrated hydrological data;

- a comparison of streamflow and discharge characteristics between the reference and projection periods.

The scheme of the research procedure is presented in Figure 2. 
The model calibration was conducted using streamflow data from a chosen five-year period covering the years 1968-1972. During this period, there were both relatively high and low flows. The Monte Carlo approach was used to randomly generate the parameter sets of the model. Different efficiency criteria were applied to assess the "closeness" of the simulated (modelled) streamflow to the observed one. They comprise the efficiency objective function $-\mathrm{R}_{\text {eff }}$, the efficiency objective function using the logarithm of streamflow $-\mathrm{R}_{\text {efflog }}$, the coefficient of determination $-\mathrm{R}^{2}$, and the mean difference - M (Seibert 2005). The first three measures should be as close as possible to the value of 1 to represent a perfect fit, whilst the last one should be equal to zero. The best results of the objective functions were obtained for three sets of model parameters (Tab. 1). The preliminary calibration of the model was reported in an earlier study (Somorowska, Piętka 2012) and is revisited here by applying an alternative response function with delay. The values of the model parameters from the current calibration are shown in Table 2 . In all cases the values of $\mathrm{R}_{\text {eff }}$ and $\mathrm{R}^{2}$ were over 0.8 , the values of $\mathrm{R}_{\text {efflog }}$ were equal to or greater than 0.7 and the values of $\mathrm{M}$ were equal to zero. Based on that it was assumed that all three parameter sets gave relatively acceptable simulations and the simulated streamflow over the reference period shows high conformity with the observed one. An example of the course of streamflow simulated with parameters from the set no. 2 is shown in Figure 3. However, on the scatter plot of the observed versus simulated streamflows it is clearly visible that the simulated values are slightly below the observed ones (Fig. 4). For three sets of parameters the average simulated streamflows were within the range of $0.89-0.91$ of the observed in the years 1968-1972. For the periods of validation (1991-1995 and 2007-2011) the possible lower limit of underestimation was slightly greater and lies within the range of $0.85-0.92$. In order to incorporate the uncertainty estimation, the mean correction factor was implemented to the simulated streamflow. An analysis of streamflow for the future climate conditions in $21^{\text {st }}$ century was performed using modelled streamflow values as well as those multiplied by the factor 1.19 (reciprocal of the 0.85 factor) indicating the uncertainty level.

Table 1. Values of the objective functions obtained during the calibration of the model for the years 1968-1972

\begin{tabular}{|c|c|c|c|}
\hline Objective function & Set no. 1 & Set no. 2 & Set no. 3 \\
\hline $\mathrm{R}_{\text {eff }}$ & 0.837 & 0.836 & 0.827 \\
\hline $\mathrm{R}^{2}$ & 0.837 & 0.836 & 0.827 \\
\hline $\mathrm{R}_{\text {efflog }}$ & 0.712 & 0.710 & 0.697 \\
\hline $\mathrm{M}$ & 0 & 0 & 0 \\
\hline
\end{tabular}

There are a number of different indicators of hydrological alteration applied to assess changes in the river regime. The Indicators of Hydrologic Alteration (IHA) comprising 32 different hydrologic parameters are widely used (Richter et al. 1996). Based on 
Table 2. Parameter values of the best fit sets obtained in the calibration procedure using the Monte Carlo method

\begin{tabular}{|c|c|c|c|}
\hline Model parameter & Set no. 1 & Set no. 2 & Set no. 3 \\
\hline TT & -0.551 & -0.495 & -0.600 \\
\hline CFMAX & 2.384 & 2.370 & 2.300 \\
\hline SFCF & 0.943 & 0.937 & 0.950 \\
\hline CFR & 0.000 & 0.001 & 0.001 \\
\hline CWH & 0.141 & 0.148 & 0.132 \\
\hline FC & 158 & 162 & 193 \\
\hline LP & 0.57 & 0.59 & 0.66 \\
\hline BETA & 3.520 & 3.540 & 3.537 \\
\hline ALPHA & 0.51 & 0.53 & 0.52 \\
\hline K1 & 0.038 & 0.039 & 0.043 \\
\hline K2 & 0.001 & 0.001 & 0.001 \\
\hline MAXBAS & 5.58 & 6.05 & 5.80 \\
\hline PART & 0.760 & 0.760 & 0.815 \\
\hline DELAY & 12 & 6 & 22 \\
\hline
\end{tabular}

Explanation of symbols: TT - target temperature $\left({ }^{\circ} \mathrm{C}\right)$, CFMAX - degree-day factor $\left(\mathrm{mm}^{\circ} \mathrm{C}^{-1} \mathrm{day}^{-1}\right)$, SFCF- snowfall correction factor $(-), \mathrm{CFR}$ - refreezing coefficient $(-), \mathrm{CWH}$ - water holding capacity $(-), \mathrm{FC}$ - maximum soil moisture ( $\mathrm{mm}), \mathrm{LP}$ - soil moisture threshold for the reduction of evaporation, BETA - shape coefficient (-), ALPHA - non-linearity coefficient (-), K1 and K2 - recession coefficients $\left(d^{-1}\right)$, MAXBAS - routing, length of the weighting function (d), PART - portion of the groundwater recharge $(-)$, DELAY - period over which the remaining portion of recharge is evenly distributed (d).

that the Dundee Hydrological Regime Assessment Method (DHRAM) was developed, classifying the degree of alteration to hydrological regime using a five-point scale which refers to the risk of ecological damage (Black et al. 2005). Some studies address the need to develop guiding principles to aid the choice of the most important river flow indices from a large set of possible parameters (e.g. Monk et al. 2007). In other studies it is proposed to minimize statistical redundancy by selecting a small set of representative indicators (Gao et al. 2009). In this study basic indicators of change have been applied based on the chosen IHA indicators. These include the magnitude of monthly streamflows, the magnitude of annual discharge and the timing of monthly streamflows. The comparison was based on the streamflow characteristics derived for the reference period (1961-2000) and the projection period (2021-2060). The range of annual discharge values in the past and future was studied using curves of the annual cumulative discharge amount. For the study catchment, Figure 5 shows the mean monthly values of meteorological variables in the reference period compared to the projection period. Under the A1B scenario, air temperature is expected to increase slightly in all months, on average by $1.35^{\circ} \mathrm{C}$ (Fig. $5 \mathrm{~b}$ ). Mean annual precipitation is 
expected to increase by $55 \mathrm{~mm}$ (Fig. 5a). There is also projected an increase in mean annual evapotranspiration, by $17 \mathrm{~mm}$ (Fig. 5c), as well as in mean annual potential evapotranspiration, by $22 \mathrm{~mm}$ (Fig. 5d).
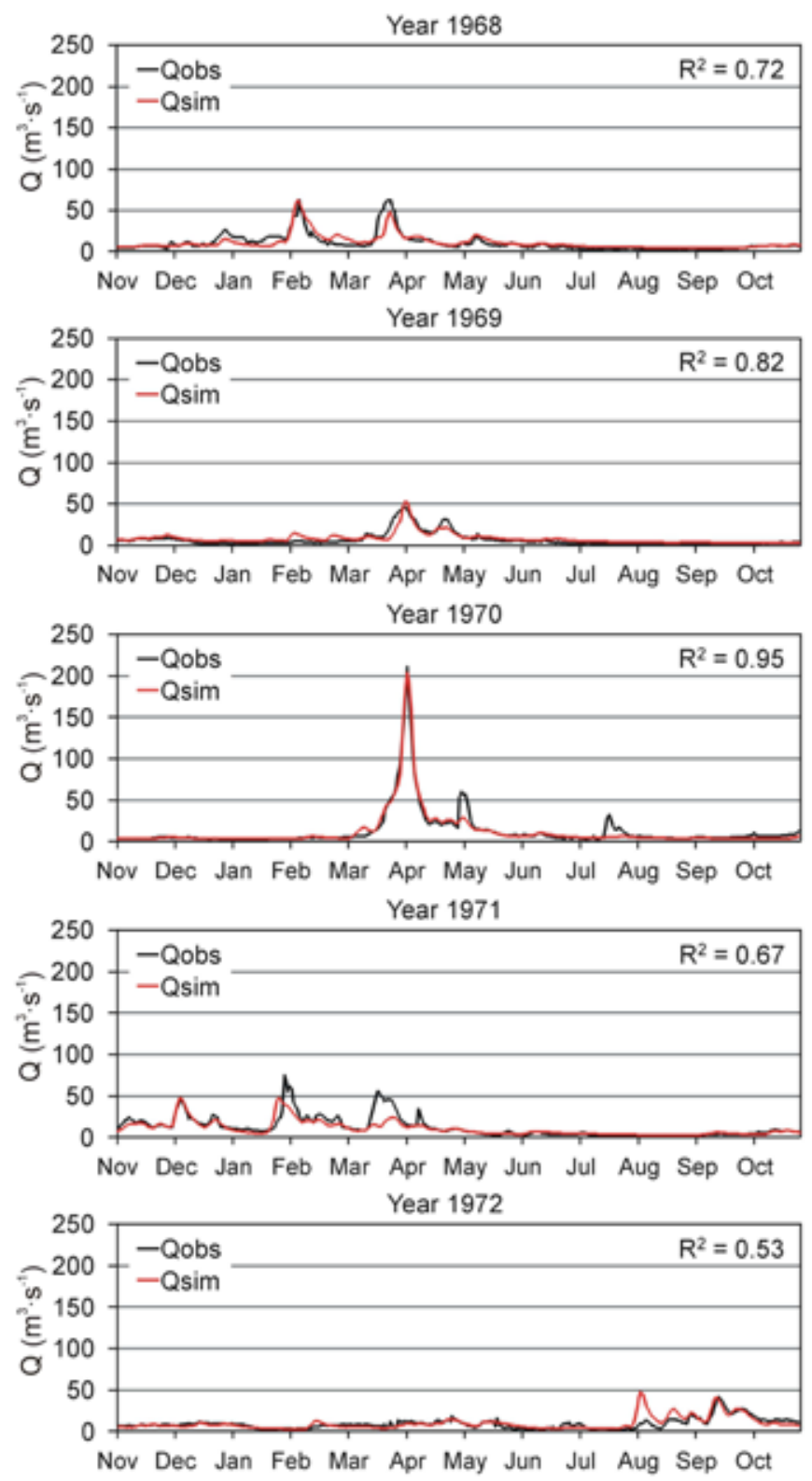

Figure 3. Simulated streamflow with parameters from the set no. 2 against the observed values in the years 1968-1972, for which the model calibration was done.

The coefficient of determination $\left(\mathrm{R}^{2}\right)$ was calculated separately for each hydrological year 
a)

b)

c)

Calibration with parameter set no. 1

Calibration with parameter set no. 2

Calibration with parameter set no. 3
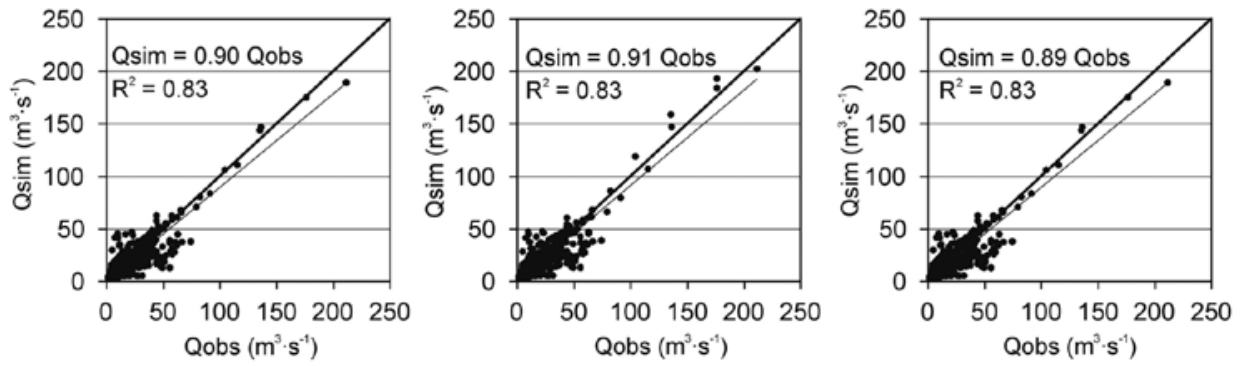

Figure 4. Scatter plot of the simulated against observed streamflows for the model calibration with parameter set no. 1 (a), set no. 2 (b) and set no. 3 (c).

The bold black line symbolizes the relation 'Qsim = Qobs', whereas the linear regression line is plotted in grey color

a)

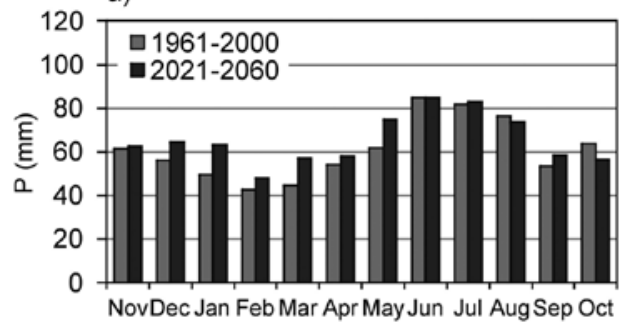

b)

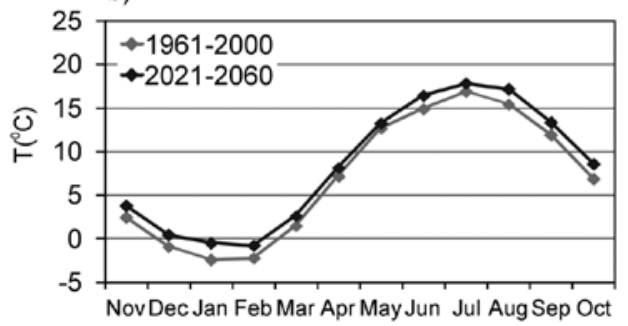

c)

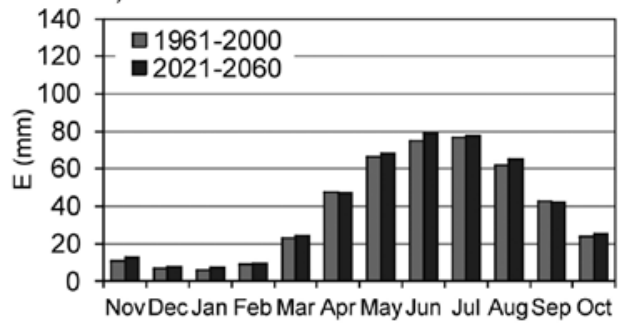

d)

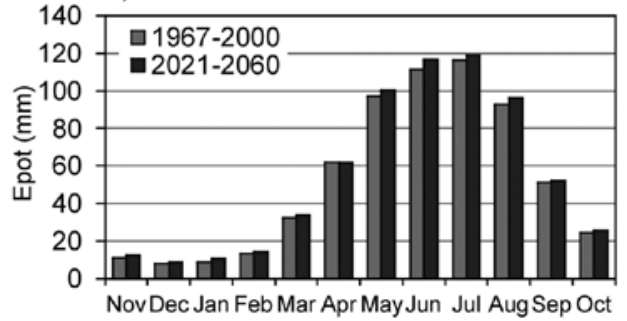

Figure 5. Values of precipitation (a), air temperature (b), evapotranspiration (c) and potential evapotranspiration in the reference period and in the projection period for the years 2021-2060 predicted by the CLM climate model.

In the case of potential evapotranspiration the reference period starts from the year 1967 due to limited data availability at the ground reference station 
STREAMFLOW IN THE 20 ${ }^{\text {TH }}$ CENTURY AND ITS PROJECTION OF CHANGE IN THE 21 ${ }^{\text {ST }}$ CENTURY

First, the impact of the expected climate change was examined by comparing the daily streamflow course in the reference period and in the future period (Fig. 6). In the course of the observed hydrograph two sub-periods can be distinguished. In the years 1961-1980 relatively high daily streamflows appeared with the maximum over $270 \mathrm{~m}^{3} \cdot \mathrm{s}^{-1}$. In a gradually warming climate relatively lower streamflows were observed in the years 1981-2000 with the maximum not exceeding $150 \mathrm{~m}^{3} \cdot \mathrm{s}^{-1}$. From model simulations it is predicted that future maximum streamflows will continue as in the last decades of the $20^{\text {th }}$ century.

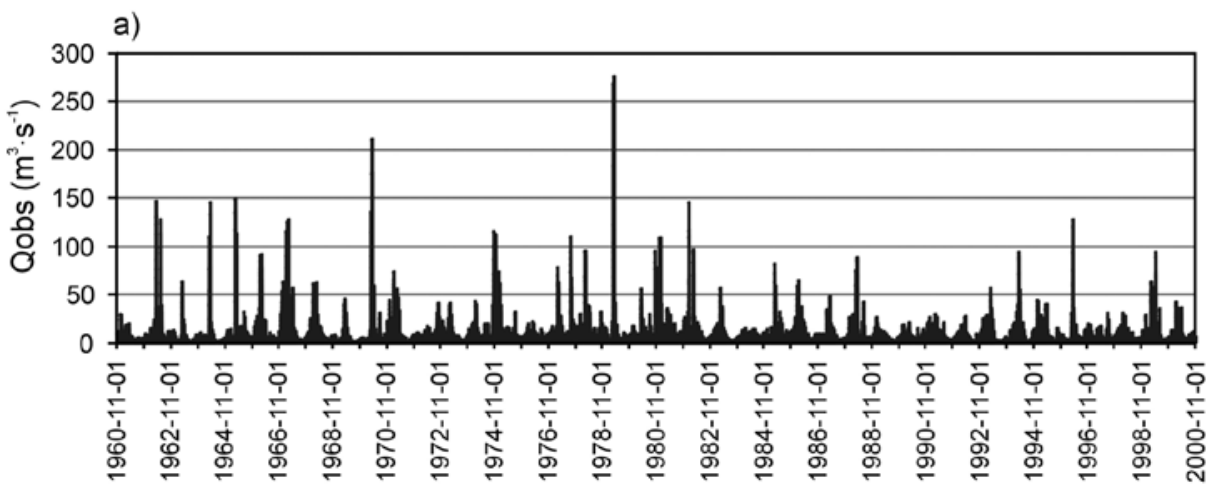

b)

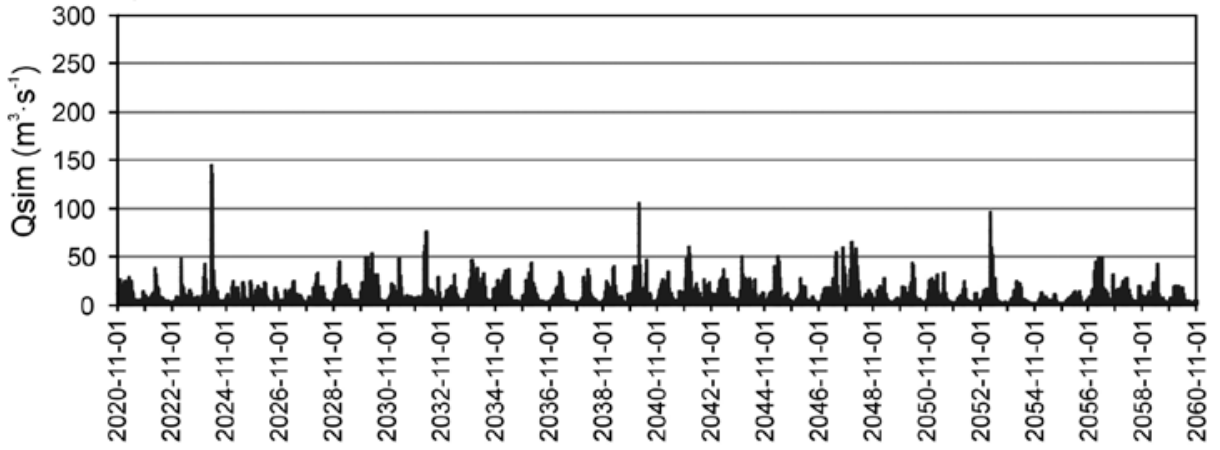

Figure 6. Daily streamflow evolution for the period 1961-2000 (a) and in the projection period for the years 2021-2060 (b)

Figure 7 shows the expected change in the monthly streamflow (Fig. 7a) and corresponding values of the monthly discharge (Fig. 7b). Generally, the seasonal cycle is predicted to follow the historical type, though an amplification of the cycle might be expected in one winter month (January) and one summer month (August). The predicted increase in precipitation in the months from November to May will not 
a)

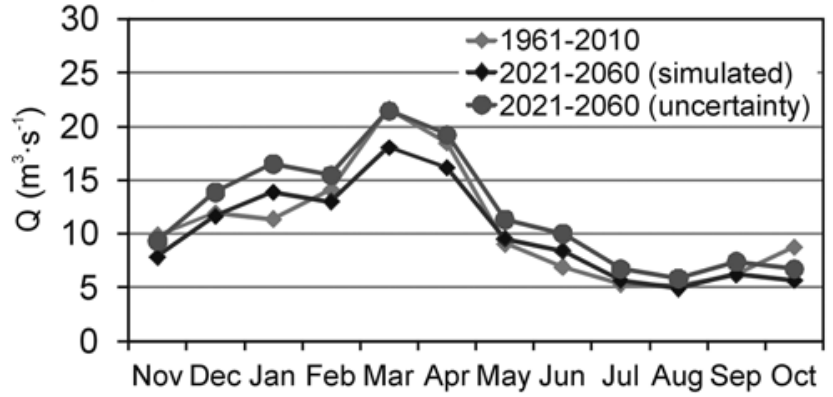

b)

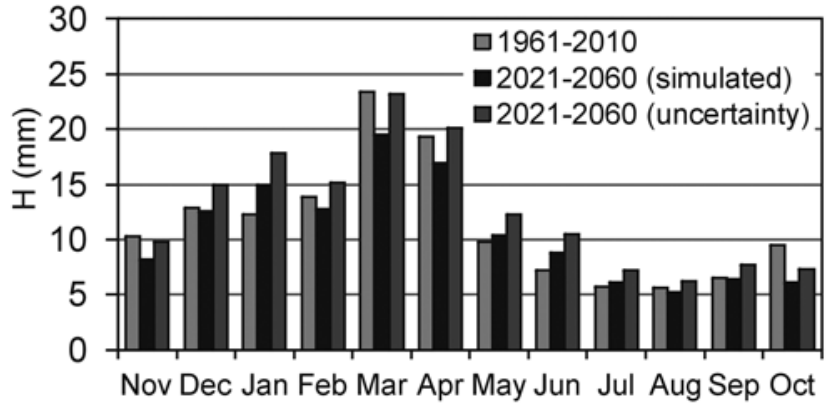

Figure 7. Mean monthly values of streamflow (a) and discharge (b) in the reference 1961-2010 and projection 2021-2060 periods. For the projection period values concern these simulated by the calibrated model (simulated) and those including uncertainty
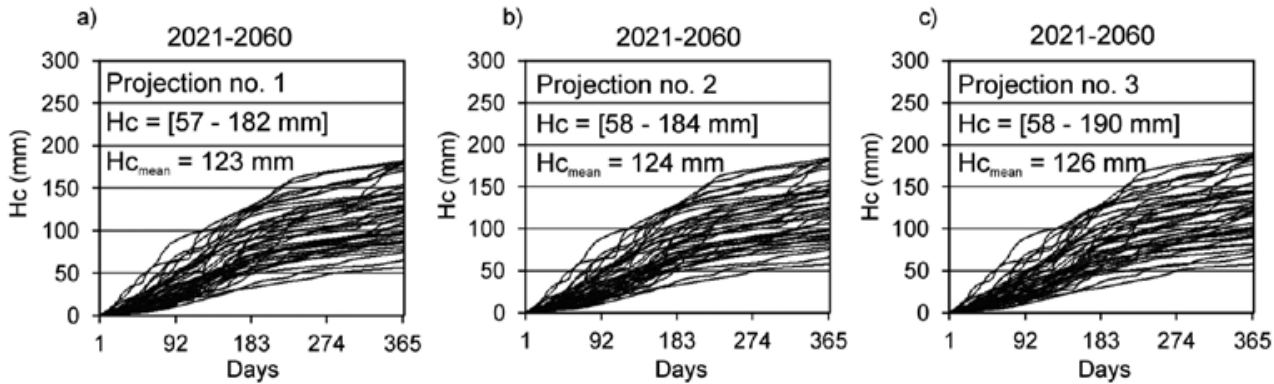

Figure 8. Annual cumulative discharge curves for the projection period for the years 2021-2060 based on simulations with the parameters of set no. 1 (a), set no. 2 (b) and set no. 3 (c) 

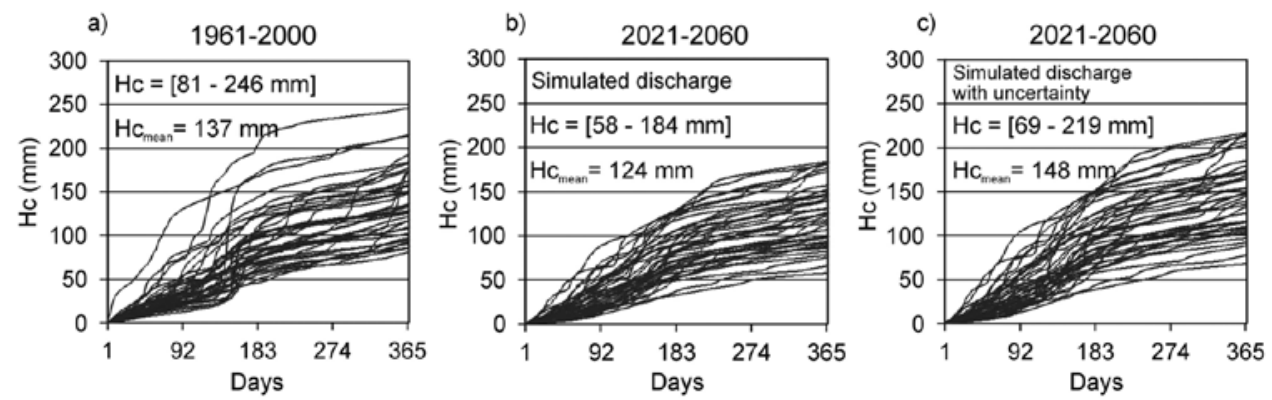

Figure 9. Annual cumulative discharge curves for the reference period (a), for the projection no. 2 as simulated (b) and for the projection no. 2 as simulated with the upper limit of uncertainty (c)

give an increase in flow except the flows in January. The streamflow in August is expected to decrease slightly due to the combination of increased temperature and consequent increased evaporation. Consideration of streamflow values with the correction factor shows the upper uncertainty band. The mean annual discharge in the years 1961-2000 was equal to $142 \mathrm{~mm}$, whereas mean predicted value was 124 $\mathrm{mm}$ from model simulations and $148 \mathrm{~mm}$ as the upper limit. The results show that there is a risk of a decrease in river water resources, however due to the uncertainty of model simulations it is also possible that the mean in the reference period might be slightly exceeded. Figure 8 shows the range of annual cumulative discharge curves for the future projections. By using three sets of model parameters, the results are similar (Fig. 8a-c).The maximum cumulative discharges in the future, both for the model simulated values and for the corrected values are below the values in the reference period (Fig. 9). In the reference period exceptionally high annual discharges took place in $1967(246 \mathrm{~mm})$, in $1975(214 \mathrm{~mm})$ and in $1979(215 \mathrm{~mm})$. The lowest discharge appeared in 1963 with the value of $81 \mathrm{~mm}$. A different range is predicted by the model for the future. It is expected to be within the range of $58-184 \mathrm{~mm}$ as modelled and within the range 69-219 $\mathrm{mm}$, if considering the correction factor.

It is important to emphasize that the prediction of streamflow changes was based only on the selected climate model simulations applied as an input into the hydrological model. Therefore, the results cannot be considered as definitive. Climate variables such as temperature and precipitation are simulated by different climate models with different accuracy. Hence the degree of uncertainty associated with the climate predictions has direct influence on the uncertainty of streamflow simulations. Therefore this impact study is planned to be broaden in the next research phase and based on a larger number of climate models to assure ensemble prediction and to consider a full range of possible streamflow changes. 


\section{SUMMARY}

This study concerns the inter-annual and seasonal variability and changes in the streamflow of a mesoscale catchment in Poland in current and future climate conditions. The investigated hypothesis dealt with the extent of the river regime changes in terms of future climate. Changes in the seasonal regime of the streamflow and discharge were analysed, based on the continuous model simulations for the $20^{\text {th }}$ and $21^{\text {st }}$ centuries.

The results indicate that in the last two decades of the $20^{\text {th }}$ century a decrease in maximum daily streamflows was a fact. In the next years, as projected for 2021-2060, a decrease in the annual discharge characterizing the river water resources may appear. It is possible that the minimal annual discharge may decrease from $81 \mathrm{~mm}$ registered in the year 1963 to the value of approximately $60 \mathrm{~mm}$. The maximal annual discharge may also decrease from the value of $246 \mathrm{~mm}$ observed in the year 1967 to the values within the range $184-219 \mathrm{~mm}$.

The decrease of river water resources, coinciding with the greatest demand for water by plants, may consequently reduce the availability of water for natural ecosystems and agroecosystems which are most common in central Poland. The possible consequences of changing streamflows caused by the projected climate change are a signal to take adaptation action. Thus the problem of reliable prediction requires further research, including extended uncertainty analysis, as well as ensemble simulations using meteorological variables from different regional climate models to reflect the widest possible range of projected changes, and thus to reduce the uncertainty of the projection.

\section{ACKNOWLEDGEMENTS}

This paper is based on data supplied by the World Data Center for Climate (WDCC), Hamburg, Germany. Long term series of precipitation, evapotranspiration and air temperature were extracted from the following experiments: (1) Climate Simulation with CLM, Climate of the $20^{\text {th }}$ Century and (2) Climate Simulation with CLM, Scenario A1B. The support from Max-Plank-Institute, SGA Service Group Adaptation, who provided free access to data, is much appreciated. The HBV-Light model used in this study was kindly provided by Prof. Jan Seibert of the University of Zurich.

\section{REFERENCES}

Black A.R., Rowan J.S., Duck R.W., Bragg O.M., Clelland B.E., 2005, DHRAM: A method for classifying river flow regime alterations for the EC water framework directive, Aquatic Conservation, 15, 427-446. 
Döll P., Müller Schmied H., 2012, How is the impact of climate change on river flow regimes related to the impact on mean annual runoff? A global-scale analysis, Environ. Res. Lett., 7, 1, 014037, pp. 11.

Gao Y., Vogel R., Kroll C. N., Le Roy Poff N., Olden J. D., 2009, Development of representative indicators of hydrologic alteration, Journal of Hydrology, 374, 136-147.

Hollweg H-D., Böhm U., Fast I., Hennemuth B., Keuler K., Keup-Thiel E., Lautenschlager M., Legutke S., Radtke K., Rockel B., Schubert M., Will A., Michael Woldt M., Wunram C., 2008, Ensemble Simulations over Europe with the Regional Climate Model CLM forced with IPCC AR4 Global Scenarios, Tech. Rep., No. 3.

MARS, 2007, Monitoring of Agriculture with Remote Sensing, http://mars.jrc.it/

Monk W.A., Wood P.J., Hannah D.M., Wilson D.A., 2007, Selection of river flow indices for the assessment of hydroecological change, River Research and Applications, 23, 113-122.

Projekt Narodowej Strategii Gospodarowania Wodami 2030 (Project of the National Strategy for Managing Water Resources 2030), 2008, Kindler J. (ed.), PROEKO CDM Sp. z o.o., Warszawa.

Richter B.D., Baumgartner J.V., Powell J., Braun D.P., 1996, A method for assessing hydrologic alteration within ecosystems, Conservation Biology, 10, 1163-1174.

Seibert J., 1997, Estimation of parameter uncertainty in the HBV model, Nordic Hydrology, $28,4 / 5,247-262$.

Seibert J., 2005, HBV light version 2, User's manual, Environmental Assessment, SLU, Uppsala, Sweden.

Seibert J., Vis M.J.P., 2012, Teaching hydrological modeling with a user-friendly catchmentrunoff-model software package, Hydrol. Earth Syst. Sci. Discuss., 9, 5905-5930.

Soczyńska U., Gutry-Korycka M., 2000, Prognozowanie ustroju hydrologicznego w różnych skalach geograficznych (Forecasting of hydrological regime in different geographical scales), Przegląd Geofizyczny, 45, 4/5, 239-250.

Somorowska U., Piętka I., 2012, Projekcja zmian ustroju hydrologicznego w skali zlewni $w$ warunkach fluktuacji klimatycznych (Projection of changes of hydrological regime under the conditions of climate fluctuations), [in:] Marszelewski W. (ed.), Gospodarowanie woda $w$ warunkach zmieniajacego się klimatu (Water management under changing climate), Monografie Komisji Hydrologicznej PTG, Toruń.

Sperna Weiland F.C., van Beek L.P.H., Kwadijk J.C.J., Bierkens M.F.P., 2012, Global patterns of change in discharge regimes for 2100, Hydrol. Earth Syst. Sci., 16, 1047-1062.

Szwed M., Karg G., Pińskwar I., Radziejewski M., Graczyk D., Kędziora A., Kundzewicz Z.W., 2010, Climate change and its effect on agriculture, water resources and human health sectors in Poland, Nat. Hazards Earth Syst. Sci., 10, 1725-1737. 